\title{
A NEW AMPHIBIAN CESTODE *
}

\section{Lloyd B. Dickey}

Few cestodes have ever been described from amphibian hosts. Nematotaenia dispar (Goeze 1782) has been reported from Europe by Schmidt (1885), and by Fuhrmann (1895); and from America by Stiles and Hassall $(1912 ; 277)$. Taenia pulchella Leidy 1851 was reported from America in Bufo americanus, at the time of its original description. Jewell (1916) described Cylindrotaenia americana from America in Acris gryllis, Rana pipiens, Rana virescens, and Bufo lentiginosus. These three species, together with two Proteocephalids, Ophiotaenia hylae from Australia, and O. schultzei from Africa (Johnston, 1912), constitute the species so far described from frogs and toads. Johnston (1916:194) reports the presence of a new species of Nematotaenia in Australia, which has not yet been described. Larval stages of Sparganum have been known to occur in European frogs, but nothing is known of the larval stages of any of the adult cestodes thus far reported in Anurans.

Jewell (1916) has pointed out the discrepancies of Schmidt's description of Nematotaenia dispar (Schmidt 1855) as compared with the recognized, original form first described by Goeze (1782), and later by Fuhrmann (1895). It is probable that Schmidt's material was not Nematotaenia dispar, since he describes the worm as having a neck, with the greatest diameter at the posterior end, and an oval cirrus sac about twice as long as it is broad. Fuhrmann's description includes a worm devoid of a neck, the greatest diameter of the strobila being at the anterior end, with the cirrus sac about ten times as long as broad.

Lühe (1899:526) proposed the genus Nematotaenia, to contain Taenia dispar Goeze: His first characterization of the new genus, however, appears in a later paper (Lühe 1910), as follows: "Taenien mit unbewaffnetem Scolex, ohne Rostellem, mit drehrundem Körper, der in seinem vorderen Abschnitt etwas dicker ist und nach hinten allmählich dünner und schliesslich fadenförmig wird. Gliederung nur am Hinterende ausgesprochen, wo sich die reifen Proglottiden, die wesentlich länger als breit sind, einzeln ablösen, um dann lebhaft beweglich noch längere Zeit weiterzuleben. Gesclechtsöffnungen randständig, unregelmässig abwechselnd. Hoden in der Zweizahl, dorsal und annähernd symmetrisch. Dotterstock fast genau in der Achse

* Contributions from the Zoological Laboratory of the University of Illinois No. 177. 
des Körpers; Keimstock ventral, der Genitalöffnung wenig genähert. Geschlechtswege dorsal von Wassergefässen und Marksträngen. Uterus frühzeitig in einzelne Eikapseln zerfallend, welche je 2-4 (meist 3) Eier enthalten. Eier mit 3 Hüllen. Finnenstadium unbekannt.

"Im Daim von Amphibien. Bisher nur eine Art bekannt." "

Jewell (1916:191) gives the following diagnosis for Cylindrotaenia: "Scolex, unarmed, without rostellum; reproductive organs single in each proglottid; pores lateral, alternating; vagina and cirrus dorsal to the excretory canals and main nerve trunk; testis one, dorsal; ovary and vitellaria ventral. Uterus breaks up into capsules surrounding the embryos which ultimately pass into two parauterine capsules." Cylindrotaenia americana "from the small intestine of various Anura" is designated as the type.

\section{MORPHOLOGY OF THE NEW FORM}

The present study is based upon material collected at Oxford, Georgia, in July 1916, from two host specimens of Bufo lentiginosus. Of the adult specimens, two bore ripe proglottids, and each measured about $100 \mathrm{~mm}$. in length. Eleven young worms, which varied in length from 3.5 to $5 \mathrm{~mm}$., were collected from a single host.

The worm is cylindrical in form anteriorly. In the region of the strobila where the reproductive organs attain the maximum of development, the segments are oval in cross-section, being compressed laterally (Fig. 1). In a typical specimen, the cross-section is circular in outline at a distance $6 \mathrm{~mm}$. from the tip of the scolex, is oval at a distance of $13 \mathrm{~mm}$., and the circular form is again assumed at a distance of $40 \mathrm{~mm}$., in the region where the eggs have passed into the parauterine capsules and the uterus has broken up.

No external segmentation is apparent in the anterior region of the worm. It occurs rather distinctly from 48 to $60 \mathrm{~mm}$. from the scolex. Here the segments begin to elongate and measure $0.24 \mathrm{~mm}$. in length, and $0.39 \mathrm{~mm}$. in diameter. The last few proglottids of the strobila measure 0.58 to $0.66 \mathrm{~mm}$. in length and 0.18 to $0.24 \mathrm{~mm}$. in diameter.

The scolex is unarmed, spherical, and broader than the neck. In adult specimens it measures 0.52 to $0.62 \mathrm{~mm}$. in diameter. The neck averages $0.48 \mathrm{~mm}$. in width. In young worms the diameter of the scolex is 0.26 to $0.33 \mathrm{~mm}$. The suckers are situated near the tip of the scolex. They are unarmed, and have a diameter in the adult forms of from 0.093 to $0.14 \mathrm{~mm}$. The diameter of the suckers in the young worms is from 0.085 to $0.09 \mathrm{~mm}$. The lumen is directed anteriad and slightly laterad. The scolex is circular in cross-section, except through the region of the suckers, where it is slightly oval. 
Two shallow grooves, extending from the tip of the scolex to the base of the suckers, occur on opposite sides of the scolex.

From the material at hand it appears that the cuticula is composed of two layers of equal thickness. The outer layer stains more heavily. The cuticula is 4 to $5 \mu$ in thickness and is supported by a delicate basement membrane. The subcuticula consists of cells $32 \mu$ long and $4 \mu$ in diameter. The nuclei are large and stain less heavily than the rest of the cells.

The well developed longitudinal muscles are arranged in a single layer. They separate the parenchyma into a cortical and a medullary area. The latter averages about $0.296 \mathrm{~mm}$. in dorso-ventral diameter and about $0.222 \mathrm{~mm}$. in lateral diameter in the region where the reproductive organs attain their maximum development. The longitudinal strands occur at approximately $0.083 \mathrm{~mm}$. from the cuticula. About five or six small strands go to make up a large bundle. Between fifty and sixty of these bundles, occur at more or less regular intervals. Many of them extend from one segment to another. Between subcuticula and cuticula the longitudinal fibers of the subcuticular muscles can barely be discerned. No trace of dorso-ventral muscles was found. The muscle strands of the longitudinal system are large and numerous, and are massed together at the tip of the scolex. There are also transverse muscles running concentric to the basement membrane of the suckers.

The ventral excretory canals are about $32 \mu$ in diameter. They pass lateral to the ovary about $50 \mu$ from the nearest longitudinal muscle strands. Commissures of the ventral excretory canals may be seen in the region where the reproductive organs first differentiate from the medullary parenchyma. These have a diameter of about $3 \mu$. The dorsal excretory canals are very small, and are seldom discernible. They appear most prominently in the region where the testes first become differentiated and here they often have a diameter of $8 \mu$. In the region of the scolex, they sometimes anastomose with the other excretory canals. The excretory system is continuous from one proglottid to another throughout the strobila. In the ripe proglottids the ventral canals present undulations, due to their position exterior to the developing parauterine capsules.

The two main lateral nerve trunks run parallel to and midway between the dorsal and ventral excretory vessels.

The genital rudiments are first seen at about 2 to $3 \mathrm{~mm}$. from the tip of the scolex. They appear here merely as a dark streak running through the center of the proglottids. The testes are the first organs to become differentiated from the parenchyma. The ovary arises next, and the vitelline gland forms dorsad of the latter immediately afterwards. The testes are distinguishable 3 to $4 \mathrm{~mm}$. from the sco- 
lex. No external segmentation is apparent at this point. The internal or genital segmentation can be distinguished, however, the segments being 0.04 to $0.05 \mathrm{~mm}$. long. All of the reproductive system, except the cirrus sac and vagina, is accommodated within the medullary parenchyma (Fig. 1). The genital pores are lateral and marginal, and alternate irregularly. The cirrus sac and vagina open into the genital atrium dorsal to the excretory canals and main nerve trunk.

The male organs are situated dorsally in the proglottid. The testes, two in number, are about $67 \mu$ in diameter at their greatest development. They are lenticular in shape and circular in cross-section, the antero-posterior thickness averaging $40 \mu$. This compression in the antero-posterior direction may be due to the contraction of the worm when killed, and the organs are probably spherical in shape in the live worm. A thin membrane surrounds each testis and is continuous with the walls of the vas deferens. The vasa efferentia, one from each testis, meet to form the vas deferens, near the testis on the poral side of the proglottid. After forming one or two short loops during its course, it passes into the cirrus sac (Fig. 1). The cirrus proper is surrounded by parenchymatous tissue composed of small cells with spherical nuclei. The cirrus pouch is flask shaped and is about one and a half times as long as it is broad. The length averages $48 \mu$, and the diameter $31 \mu$.

The ovary is a spherical organ, lying in the ventral half of the medullary region and slightly to the poral side of the proglottid. . The diameter averages $67 \mu$. Numerous spherical cells, each enclosed in a capsule, make up the organ. The capsules average $12 \mu$ in diameter. The vitelline gland, also spherical in shape, lies dorso-lateral to the ovary but ventral to the genital pore. Its diameter averages $35 \mu$. The vitelline duct is directed laterad and meets the oviduct, which extends laterally and dorsally. The oviduct is continuous with the vagina, which in turn leads ventral to the cirrus pouch, running adjacent to it from the inner end of the latter.

The beginning of the uterus can be distinguished in proglottids 12 to $14 \mathrm{~mm}$. from the scolex. The uterus is horseshoe shaped in appearance (Fig. 2). It arises from the medullary parenchyma and soon almost completely surrounds the vitelline gland. The ovary and testes break down at the same time, the ovary disappearing before the testes: At the maximum development of the uterus, about 18 to $20 \mathrm{~mm}$. from the tips of the scolex, the eggs are $16 \mu$ in diameter. They are in the early stages of cleavage. The internal segments at this place are about $0.11 \mathrm{~mm}$. long. The uterus breaks down early, about 22 to $24 \mathrm{~mm}$. behind the scolex, and is replaced by the parauterine organs.

The parauterine organs arise from the parenchyma adjacent to the uterus. The strands of the meshwork of which they are com- 
posed soon arrange themselves parallel to the uterus on the anterior side of the proglottid. The whole structure from this stage on grows very rapidly. The tissue migrates inwards, replacing the uterus by capsules, and surrounding the egg at the same time (Figs. 5, 6). The capsules are early seen to have well defined walls. All trace of the ovary disappears, but the remnants of the testes apparently persist as long as any trace of the uterus itself can be found.

From eight to twelve truncated or flask-shaped cones appear, arranged in two parallel rows (Figs. 3, 4), one row dorsal, the other ventral. There are from four to six capsules in each row, their usual number being five. A sort of raphe, which is composed of numerous, small, spherical and thickly massed cells, staining a dark gray with hematoxylin, separates the capsules of the two rows as they come together in the center of the proglottid. The basal portion of the capsules is in the posterior portion of the proglottid and the longitudinal axes of the cones correspond to the longitudinal axis of the worm. A meshwork of fine fibers together with a fine granular tissue adjoins the capsules in the basal portion. The apex, capped in each instance by the darkly-stained cell-gland secretion, is situated in the anterior portion of the proglottid. The minute cells, from which the secretion is emitted, are easily distinguished at the most anterior end of the apparatus. The length of the cones increases as the proglottids become elongated. At the time the cones attain their greatest length, a distance of 60 to $70 \mathrm{~mm}$. from the head, they measure approximately $0.11 \mathrm{~mm}$. in length. The width of the base of a cone averages $0.06 \mathrm{~mm}$. in lateral diameter, and $0.09 \mathrm{~mm}$. in dorso-ventral diameter. The capped secretion averages $0.3 \mathrm{~mm}$. in width and 0.07 $\mathrm{mm}$. dorso-ventrally.

The eggs, occupying the basal portion of a cone, are three to six, usually four, in each capsule. They are oval, averaging $43 \mu$ in length, and $31 \mu$ in diameter. The embryos are still in the spherical stage, and average $19 \mu$ in diameter. The eggs have a shell about $3 \mu$ in thickness. Only a single thin membrane could be distinguished surrounding the embryo.

As the proglottid elongates the cones change in position and shape (Fig. 7). By the time the proglottids have become detached, the cones have become more spherical, especially in the apical portions, which now appear larger than the basal regions. This growth takes place at the expense of the surrounding parenchyma, the latter furnishing the nourishment necessary for the growth of the capsule. The fact that the parenchyma is much less dense at this stage than in earlier stages is easily seen in cross-sections of the proglottids. Some of the eggs migrate from the base of the cone into the apex. The bases of the cones remain clustered together, while the apical 
portions spread apart from each other irregularly in all directions. This is caused by the total disappearance of the raphe composed of the numerous small, spherical cells, which heretofore held the capsules together in the two parallel rows. The capped secretion spreads out over the apex of each capsule. Portions of the fibrous and granular tissue at the bases of the cones may become broken off and migrate into the parenchyma. This arrangement may be distinctly seen in detached proglottids.

Since the living parasites were not obtained nothing is known of their further development.

\section{COMPARISON OF FORMS}

The form under consideration bears striking resemblances to Nematotaenia dispar (Goeze 1782). It is similar in external form and in the limitation of marked segmentation to the posterior end. The reproductive organs are similar in shape and position. There are two testes, and the ovary, vitellaria, and uterus are single in both cases. A difference occurs in the shape of the cirrus pouch. In Nematotaenia this is tubular, and about ten times as long as broad, while in the present form the cirrus pouch is flask-shaped, and about one and a half times as long as it is broad. The uterus in both forms is horseshoe-shaped, and breaks down early. The most marked differences between the two forms lie in the development, position, and number of the parauterine organs. In Nematotaenia there are developed a varying number of small parauterine organs. Ripe proglottids show from thirteen to thirty capsules, scattered irregularly throughout the parenchyma. In the new form, the number of parauterine organs is limited, the mature proglottids showing eight to twelve capsules, arranged in the two parallel rows.

The only description extant of Taenia pulchella Leidy 1851, is much too meager to permit of a satisfactory comparison with other forms. It has general similarities with the form under consideration, such as its occurrence in the same host genus and its external appearance.

Certain marked similarities occur between the new species and Cylindrotaenia americana Jewell 1916. In Cylindrotaenia the cylindrical form also occurs, and the segmentation of the strobila is evident at the posterior end only. The musculature of the two species is very similar. While in both forms the male reproductive organs are limited and definite in number, in Cylindrotaenia there is only one, and in the new form two, testes. In the former the vas deferens leads straight to the cirrus, while in the new worm there are various undulations. The female reproductive organs are very similar. 
Again, the most marked difference between the two species occurs in the number and position of the parauterine capsules. In Cylindrotaenia two truncated cones appear, one dorsal and one ventral, the parauterine capsules being thus definitely limited. In the form here described, the capsules are also limited, although not as definitely, and they are more numerous than in Cylindrotaenia, being eight to twelve in number, with the regular arrangement previously noted.

\section{SYSTEMATIC POSITION}

In the Revision of the Cyclophyllidea (Lühe 1910) a new family, Nematotaeniidae, has been created for the reception of Nematotaenia dispar. This classification does not take into consideration certain essential characters of development and morphology, which relate it more closely to other forms.

Fuhrmann (1908:29) and Ransom (1909:88) have placed Nematotaenia in the subfamily Paruterininae, with six other genera: Paruterina Fuhrmann, 1916; Culcitella Fuhrmann, 1916; Rhabdometra Kholodkovski, 1900; and Biuterina Fuhrmann, 1902. Following is Ransom's diagnosis of the subfamily (Ransom, 1909:85): "Hymenolepididae; scolex usually armed, rarely without rostellum. A single set of reproductive organs in each segment. Uterus simple or double with a single parauterine organ or multiple with several parauterine organs, into which the eggs pass in the final stage of development of the segment. Adults in birds and amphibia." Paruterina Fuhrmann, 1906, is designated as the type genus.

Nematotaenia differs greatly from the other six genera included in this subfamily. This is evidenced by its cylindrical form, its two testes, as compared with the numerous and indefinite number in the other genera, the early degeneration of the uterus and its numerous parauterine capsules.

Jewell (1916), after describing Cylindrotaenia, creates a new subfamily for its reception, and includes Nematotaenia. This new subfamily is characterized as follows: "Cylindrotaenianae: Cylindrical Dilepinidae having one or two dorsally placed testes, ovary and vitellaria ventral, vitellaria dorsal to ovary. Proglottids distinct at the posterior end only. The uterus breaks down early and the embryos are later enclosed in parauterine capsules." The same writer considers Taenia pulchella Leidy as probably belonging to this subfamily.

It is evident from the previous description of the new form, that it belongs in this subfamily. However, because of the great differences in the number and arrangement of the parauterine capsules, it cannot be placed in either the genus Nematotaenia or the genus Cylindrotaenia. The definite, regular arrangement of the capsules in two parallel 
rows would make it generically distinct. It is therefore necessary to create a new genus for the reception of this form, the diagnosis of which would read as follows: Distoichometra: Scolex unarmed, without rostellum. Body generally circular in cross-section, or nearly so. Genital pores alternating irregularly. Testes two in number, dorsal. Cirrus pouch approximately one and one-half times as long as broad. Ovary ventral. Uterus horseshoe-shaped, breaking up early into two parallel rows of egg-capsules, 4 to 6 in a row. Capsules hold 3 to 6 eggs each. After breaking up of uterus, capsules remain clustered together and do not become scattered throughout the parenchyma.

Type species Distoichometra bufonis, gen. nov., sp. nov., with characters of the genus; adult from the intestine of Bufo lentiginosus.

The writer wishes to express his thanks to Professor Henry B. Ward, under whose supervision the work was done, for his helpful criticisms and suggestions.

\section{Literature Cited}

Fuhrmann, Otto. 1895.-Die Taenien der Amphibien. Zool. Jahrb., Anat., 9:207-216.

1908. Die Cestoden der Vögel. Zool. Jahrb., Suppl. 10, 232 pp.

Goeze, J. A. E. 1782.-Versuch einer Naturgeschichte der Eingeweidewüermerthierischer Körper, Blankenburg. 471 pp., 35 pls.

Jewell, Minna E. 1916.-Cylindrotaenia americana nov. sp. from the Cricket Frog. Jour. Paras., 2:181-292.

Johnston, T. Harvey. 1912.-Notes on Some Entozoa. Proc. Roy. Soc. Queensland, 24 :63-91.

1916.-Helminthological Notes. Mem. Queens. Mus., 5:186-196.

Leidy, Joseph. 1851.-Contributions to Helminthology. Proc. Acad. Nat. Sci. Phila., $5: 239-244$.

Lühe, M. 1899.-Zur Kentniss einiger Distomen. Zool. Anz., 22:524-539.

1910.-Parasitische Plattw.ürmer. II: Cestodes. In Die Süsswasserfauna Deutschlands, $18 ; 153$ pp., 174 figs.

Ransom, B. H. 1909.-The Taenoid Cestodes of North American Birds. Bull. U. S. Nat. Mus., no. 69.

Schmidt, Otto. 1855.-Ueber den Bandwurm der Frösche Taenia dispar und die geschlechtslose Fortpflanzung seiner Proglottiden. Zeitsch. ges. Naturw., $5: 1-13$.

Stiles, C. W., and Hassall, A. 1912.-Index Catalogue of Medical and Veterinary Zoology; subjects Cestoda and Cestodaria. Bull. 85, U. S. Public Health and Mar. Hosp. Serv.

Weinland, D. F. 1858.-Human Cestoides. An Essay on the Tapeworms of Man. Cambridge, 93 pp., 12 figs. 

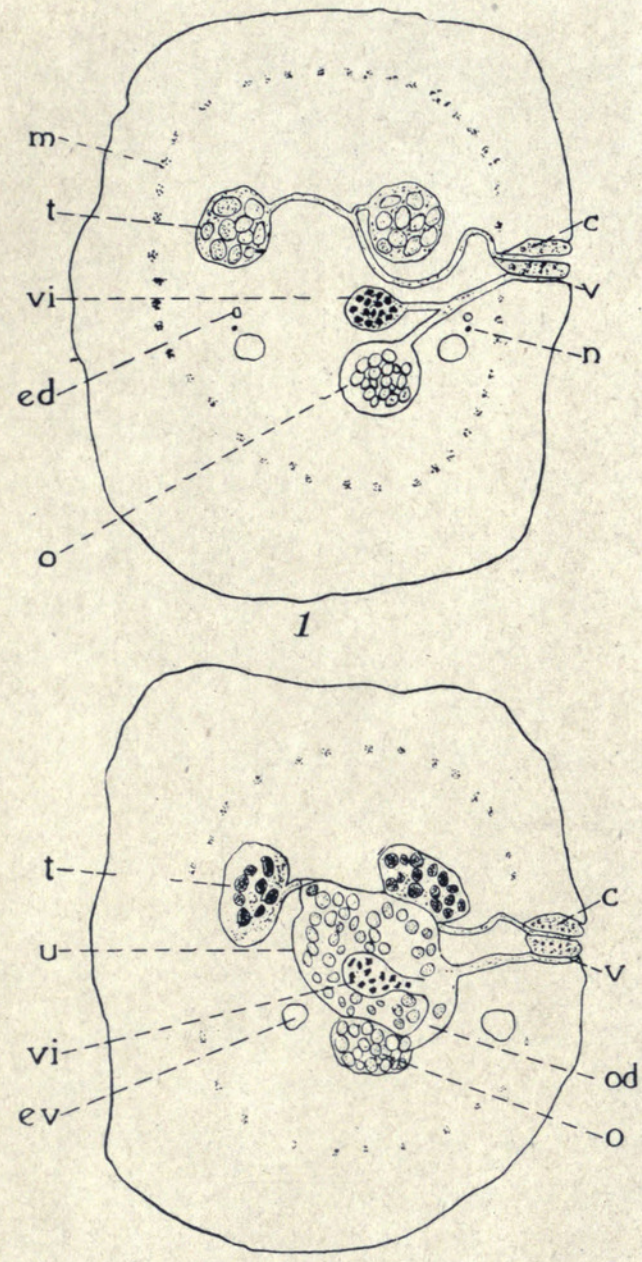

2
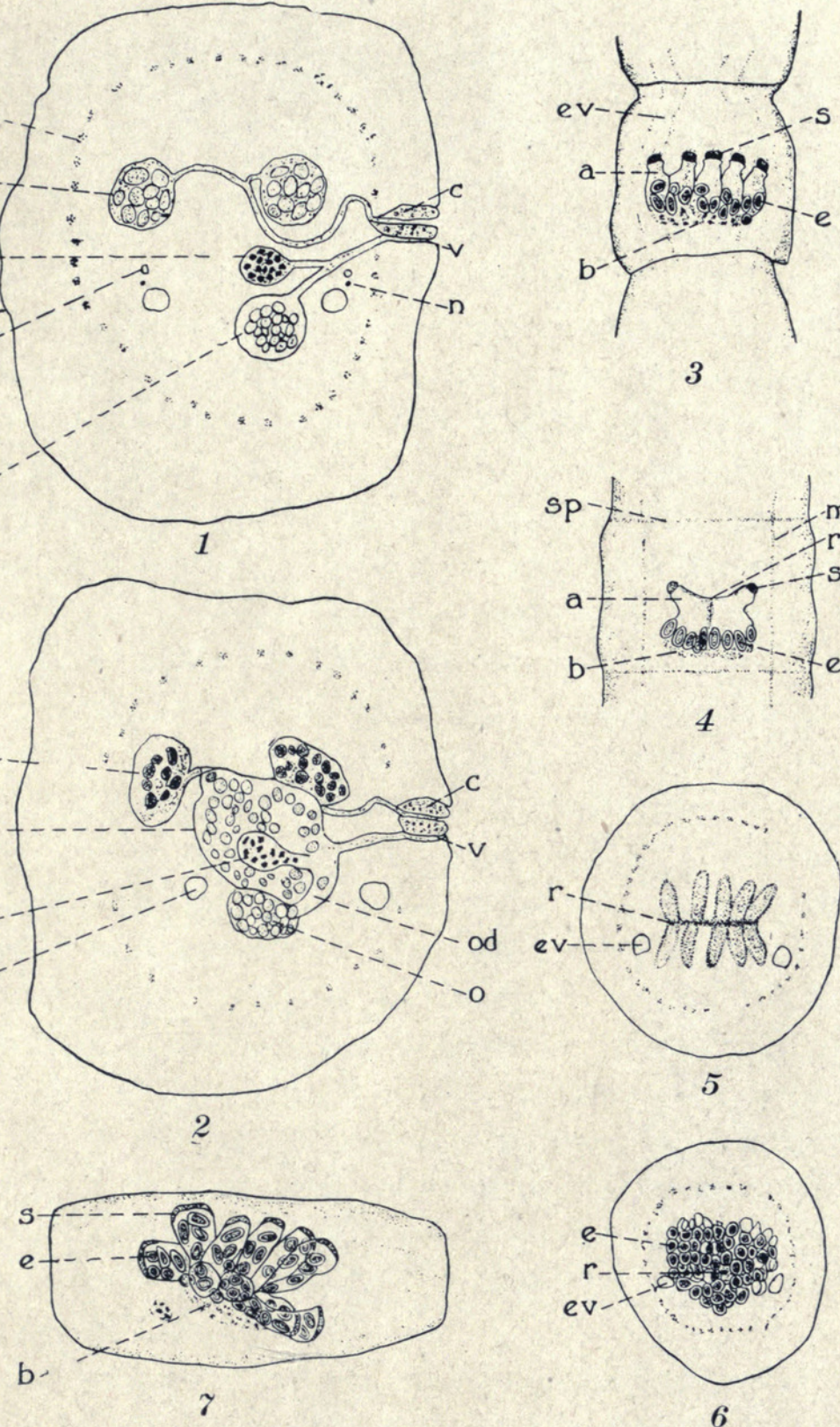

3
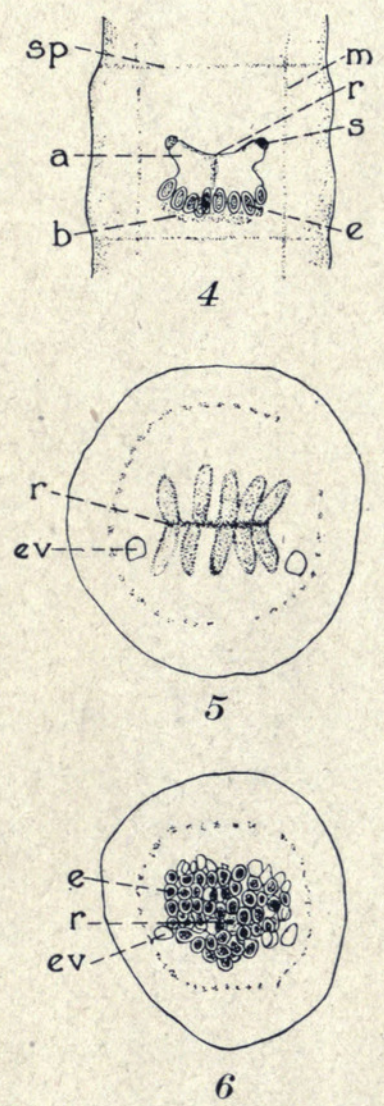

PLATE XIII

\section{Explanation of Plate}

$a$, Apical and $b$, Basal portion of parauterine organ; $c$, Cirrus pouch; $e$, Eggs in parauterine organ; $e d$, Dorsal excretory canal; $e v$, Ventral excretory canal; $m$, Longitudinal muscle; $n$, Longitudinal nerve; $o$, Ovary; od, Oviduct; $r$, Raphe; $s$, Gland-cell secretion; $s p$, Septum between proglottides; $t$, Testis; $u$, Uterus; $v$, vagina; vi, Vitelline gland.

Fig. 1.-Cross-section of mature proglottid, $\times 145$.

Fig. 2.-Later stage than fig. $1, \times 145$.

Fig. 3.-Dorsal view of ripening proglottid with parauterine capsules. Toto mount.

Fig. 4.-Lateral view of slightly earlier stage than figure 3. Toto mount.

Fig. 5.-Cross-section through apical portion of parauterine organs. $\times 65$.

Fig. 6. - Cross-section through basal portion of parauterine organs. $\times 65$.

Fig. 7.-Ripe, detached proglottid. Toto mount. 


\section{$2 \mathrm{BHL}$ Biodiversity Heritage Library}

Dickey, Lloyd Blackwell. 1921. "A new amphibian cestode." The Journal of parasitology 7(3), 129-136. https://doi.org/10.2307/3270780.

View This Item Online: $\underline{\text { https://www.biodiversitylibrary.org/item/82561 }}$

DOI: https://doi.org/10.2307/3270780

Permalink: https://www.biodiversitylibrary.org/partpdf/316324

\section{Holding Institution}

University of Toronto - Gerstein Science Information Centre

\section{Sponsored by}

University of Toronto

\section{Copyright \& Reuse}

Copyright Status: Not provided. Contact Holding Institution to verify copyright status.

This document was created from content at the Biodiversity Heritage Library, the world's largest open access digital library for biodiversity literature and archives. Visit BHL at https://www.biodiversitylibrary.org. 